Bài báo khoa hoc

\title{
Một số giải pháp phục hồi và phát triển rù̀ng ngập mặn phù hợp cho khu vực ven biển Tây, Việt Nam
}

\author{
Đoàn Thanh Vũ ${ }^{1 *}$, Trịnh Công Dân², Hoàng Thị Tố Nữ ${ }^{1}$, Nguyễn Hữu Tuấn ${ }^{1}$, Cấn \\ Thu Văn ${ }^{1}$ \\ ${ }^{1}$ Trường Đại học Tài nguyên và Môi trường TP.HCM; dtvu@hcmunre.edu.vn; \\ ctvan@hcmunre.edu.vn; nu.htt@hcmunre.edu.vn; nhtuan@hcmunre.edu.vn \\ ${ }^{2}$ Viện Kỹ thuật Biển; trinh.cong.dan@gmail.com \\ *Tác giả liên hệ: dtvu@hcmunre.edu.vn; Tel.: +84-989110983
}

Ban Biên tập nhận bài: 12/5/2021; Ngày phản biện xong: 26/7/2021; Ngày đăng bài: $25 / 10 / 2021$

Tóm tắt: Rừng ngập mặn ven biển Tây, Đồng bằng Sông Cửu Long (ĐBSCL), đóng vai trò vô cùng quan trọng cho sự tồn tại và phát triển bền vững cả về kinh tế lẫn xã hội của cả ĐBSCL. Gần $350 \mathrm{~km}$ đường bờ biển của hai tỉnh Cà Mau và Hà Tiên được chen chắn bởi rừng ngập mặn, đây là một đặc trưng rất khác biệt so với các tỉnh khác của Việt Nam nói chung và ĐBSCL nói riêng. Rừng ngập mặn ven biển ở đây không chỉ cung cấp nơi cư trú cho hệ sinh thái ven biển, rễ cây ngập mặn còn cung cấp khả năng che phủ bảo vệ đường bờ khỏi tác động của sóng và dòng chảy, những nguyên nhân trực tiếp gây ra xói lở bờ biển. Tuy nhiên những năm gần đây, đường bờ biển Tây ĐBSCL chứng kiến sự đảo chiều trong diễn biến hành thái. Nhiều đoạn bờ bị sạt lở, những dải rừng bị suy thoái. Nguyên nhân có thể kể đến là do hoạt động khai thác của con người, biến đổi khí hậu và lún sụt đất. Bài báo này đã đi vào chi tiết phân tích nguyên nhân, từ đó đề xuất những giải pháp tương ứng để giúp khôi phục rừng ngập mặn, tiến đến gây bồi tạo bãi cho vùng bờ biển Tây, ĐBSCL.

Từ khóa: Rừng ngập mặn, Đồng bằng Sông Cửu Long, Giải pháp bảo vệ rừng.

\section{1. Đặt vấn đề}

Dải bờ biển từ Mũi Cà Mau đến Hà Tiên dài khoảng $350 \mathrm{~km}$, nằm hoàn toàn về biển Tây của ĐBSCL, địa hình dải ven biển tương đối bằng phẳng và thấp, cao trình phổ biến từ $-0,5$ $\mathrm{m}$ đến $+0,8 \mathrm{~m}$ so với mực nước biển. Về chế độ thủy thạch động lực học thuộc vùng biển Tây của ĐBSCL (vịnh Thái Lan), thủy triều có chế độ nhật triều không đều, biên độ dao động nhỏ hơn $1 \mathrm{~m}$, đối lập hoàn toàn với thủy triều biển Đông có chế độ bán nhật triều, biên độ dao động rất lớn 2,1-3,8 m. Vùng biển Tây có thềm lục địa tương đối thoải và nông hơn so với vùng phía biển Đông, theo kết quả khảo sát địa hình [1] khu vực Mũi Cà Mau [2-4] cho thấy tại cao trình đáy biển $-4,0 \mathrm{~m}$ phía biển Đông cách bờ khoảng $3 \mathrm{~km}$, trong khi phía biển Tây cách bờ khoảng $7 \mathrm{~km}$, đặc biệt tại vùng bãi bồi Mũi Cà Mau cao trình đáy biển $-20 \mathrm{~m}$ cách bờ khá xa khoảng $20 \mathrm{~km}$. Địa chất khu vực này là vùng trầm tích trẻ mới hình thành có đặc điểm rất yếu dễ bị lún sụt, xói lở.

Trước những năm 1997 của thế kỷ 20, toàn bộ dải ven bờ phía biển Tây là vùng có bờ biển khá ổn định do có dải rừng phòng hộ che chắn và bảo vệ trước tác động xâm thực của sóng, gió, thủy triều [5]. Tuy nhiên, trong những năm gần đây do sức ép hoạt động khai thác của con người như xây dựng các hồ chứa thượng nguồn dẫn đến thiếu hụt về bùn cát ở hạ du trước khi đổ ra biển, xây dựng hệ thống kênh rạch tiêu thoát lũ ra biển Tây, đắp đê bao nội 
đồng chống lũ phía thượng lưu, đắp đê ngăn mặn ngọt hóa vùng bán đảo Cà Mau, khai thác nước ngầm quá mức, người dân phá rừng phòng hộ nuôi trồng thủy hải sản [6]..., cùng với những thay đổi của điều kiện tự nhiên như Biến đổi khí hậu - Nước biển dâng (BĐKHNBD), xâm nhập mặn, lún sụt đất đã tác động mạnh tới dải ven biển từ Mũi Cà Mau đến Hà Tiên. Hậu quả là dải rừng phòng hộ hiện nay bị suy thoái, tình trạng xói lở, bồi lắng dải ven biển diễn ra rất phức tạp. Đặc biệt là đoạn bờ biển từ sông Đốc thuộc huyện Trần Văn Thời đến rạch Tiểu Dừa thuộc huyện U Minh tỉnh Cà Mau dài khoảng $55 \mathrm{~km}$ bị xói lở mãnh liệt, tốc độ xói lở trung bình từ năm 2003 đến năm 2013 khoảng $30 \mathrm{~m} /$ năm, tổng diện tích bờ biển bị xói lở từ năm 1989 đến năm 2013 khoảng trên 600 ha, trung bình 50 ha/năm, trong đó xói lở chủ yếu là mất diện tích rừng phòng hộ. Đoạn bờ biển thuộc huyện An Minh tỉnh Kiên Giang cũng diễn ra tương tự như tỉnh Cà Mau. Có thể thấy, hiện nay nhiều đoạn bờ biển bị xói lở, mất trắng dải rừng phòng hộ, biển tiến sát tới chân đê biển, uy hiếp an toàn của tuyến đê biển Tây được xây dựng những năm qua. Qua hình 1 có thể thấy rõ hơn về đặc điểm đường bờ toàn bộ ĐBSCL, được chia thành 4 dạng chính: bồi tăng cường, bồi suy giảm, xói tăng cường và xói suy giảm.

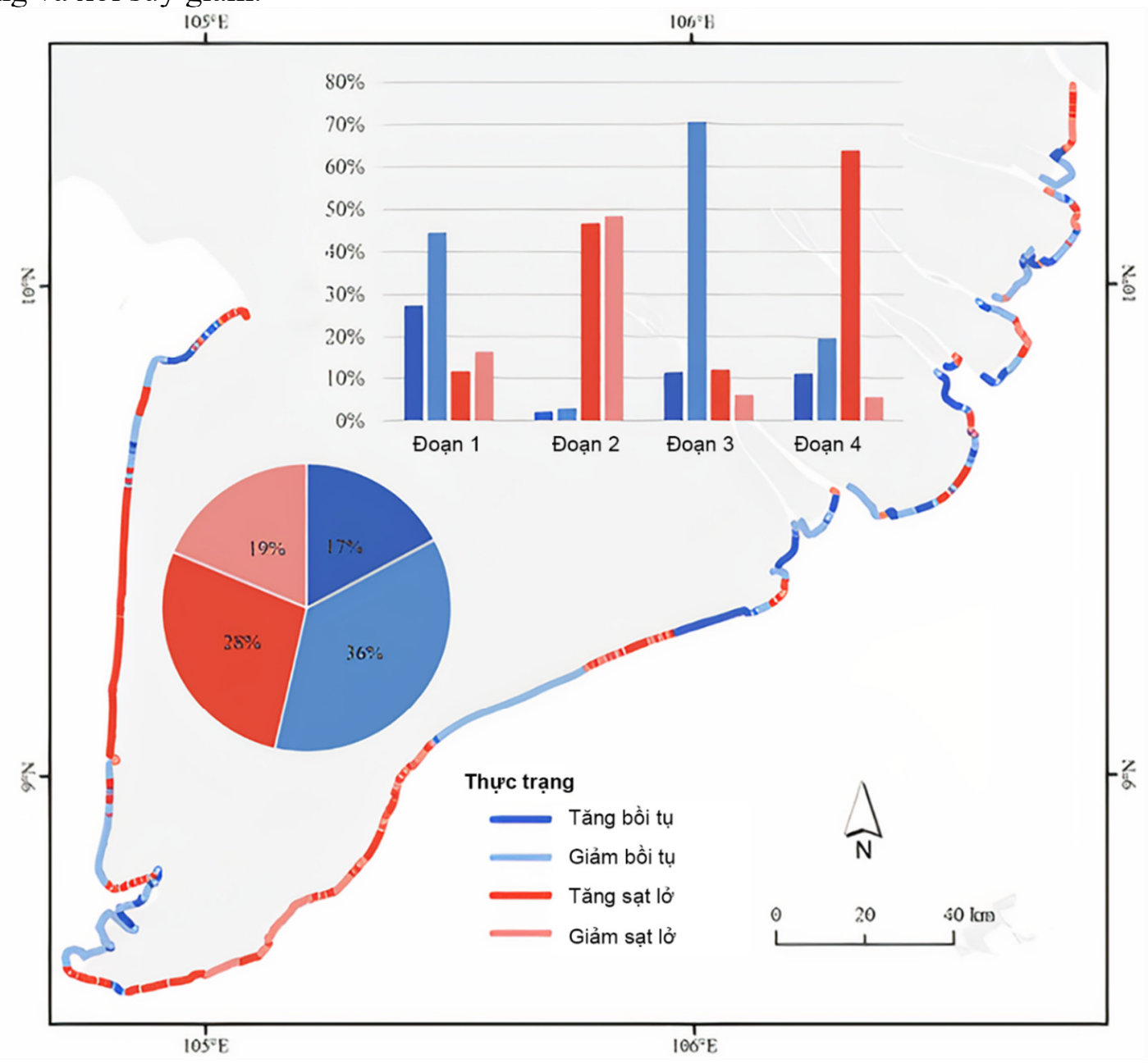

Hình 1. Đường bờ ĐBSCL có thể được chia thành 4 dạng chính: bồi tăng cường; bồi suy giảm; xói tăng cường và xói suy giảm [7].

Quá trình hình thành các bãi bồ viên biển và rừng ngập mặn (RNM) là quá trình sinh hành của bồi tụ phù sa và các quá trình sinh địa hóa diễn ra một cách tự nhiên. Theo kía cạnh địa mạo, cơ chế hình thành rừng ngập mặn được thể hiện vùng nghiên cứu được thể hiện theo sơ đồ tại hình 2. Rừng ngập mặn bờ biển Tây của ĐBSCL được hình thành trên nền địa hình bãi bồi [8]. Độ dốc bãi rất thấp $(<0,1 \%)$. Phân bố sinh học cây RNM thể hiện rõ sự phân đới về thành phần loài cây và cấu trúc cây trong các đai triều theo cao trình và thời gian phơi bãi 
(Bảng 1). Cây tiên phong xâm lấn là các quần thể cây Mắm non (Avicennia sp.). Hệ cây này bắt đầu xuất hiện ở những vùng đất có thời gian phơi bãi khoảng 3 giờ/ngày. Đây cũng là đai khởi đầu cho sự hình thành RNM tại bờ biển Tây ĐBSCL [1,9-10].

Cây Mắm non sau khi trưởng thành sẽ góp phần gây bồi, nâng cao trình bãi biển. Theo [11] cao trình được nâng lên đồng nghĩa với việc thời gian phơi bãi cũng tăng lên theo. Vòng lặp này tại điều kiện thuận lợi cho RNM phát triển xâm lấn, mở rộng về phía biển.

Bảng 1. Thời gian phơi bãi tương ứng cho các thời kỳ phát triển cây ngập mặn.

\begin{tabular}{cccccccc}
\hline Tham số & $\begin{array}{c}\text { Lạch } \\
\text { triều }\end{array}$ & Mầm 1 & Mầm 2 & Mắm non & Mắm & $\begin{array}{c}\text { Hỗn giao } \\
\text { Mắm và } \\
\text { Đước }\end{array}$ & $\begin{array}{c}\text { Được } \\
\text { chiếm ưu } \\
\text { thế }\end{array}$ \\
\hline $\begin{array}{c}\text { Thực vật } \\
\text { Chưa } \\
\text { có }\end{array}$ & $\begin{array}{c}\text { Chưa có } \\
\text { lá }\end{array}$ & $\begin{array}{c}\text { Xuất } \\
\text { hiện lá }\end{array}$ & Trên 2 lá & $\begin{array}{c}\text { Đến } 5 \\
\text { tuổi }\end{array}$ & Đến 10 tuổi & Đến 20 \\
$\begin{array}{c}\text { Thời gian phơi bãi } \\
\text { (giờ/ngày) }\end{array}$ & 0 & 3 & 4 & 5 & 7 & 9 & Trên 9 \\
Mật độ (cây/100m & & $28 \pm 8$ & $51 \pm 7$ & $68 \pm 11$ & $54 \pm 7$ & $45 \pm 9$ & $27 \pm 11$ \\
\hline
\end{tabular}

\begin{tabular}{|c|c|c|c|c|}
\hline Trầm tích biển & $\begin{array}{l}\text { Dòng triều + Dòng } \\
\text { chảy gió + Dòng } \\
\text { chảy sóng }\end{array}$ & \multirow{3}{*}{$\begin{array}{l}\text { Bãi } \\
\text { bồi } \\
\text { ven } \\
\text { biền }\end{array}$} & \multirow{3}{*}{$\begin{array}{l}\text { Chu trình } \\
\text { Sinh } \\
\text { Địa } \\
\text { Hóa }\end{array}$} & \multirow{3}{*}{$\begin{array}{l}\text { Rừng } \\
\text { ngập } \\
\text { mặn }\end{array}$} \\
\hline $\begin{array}{l}\text { Trầm tích sông + } \\
\text { Vật liệu xói lở }\end{array}$ & $\begin{array}{l}\text { Dòng chày sông, } \\
\text { lạch triều (Cửa Lớn) }\end{array}$ & & & \\
\hline $\begin{array}{l}\text { Vật liệu bào mòn } \\
\text { từ đất liền }\end{array}$ & $\begin{array}{l}\text { Dòng chảy sông } \\
\text { Bảy Háp }\end{array}$ & & & \\
\hline
\end{tabular}

Hình 2. Cơ chế hình thành rừng ngập mặn theo khía cạnh địa mạo.

\section{Những nguyên nhân chính của xói lở bờ và tiêu biến dải rừng ngập mặn ven biển}

\subsection{Biến động nguồn bùn cát lơ lưng tù thượng du sông Mekong}

Ảnh hưởng của sông Mekong đối với ĐBSCL có nhịp điệu và cường độ gần trùng với chế độ khí hậu gió mùa tại vùng nghiên cứu. Dưới tác động của gió mùa Đông Bắc bùn cát bồi lắng và dòng vận chuyển bị đẩy lệch về hướng Tây Nam (Hình 3). Bình quân hàng năm sông Mekong cung cấp khoảng 400-500 tỷ $\mathrm{m}^{3}$ nước ngọt, kèm theo 150-200 triệu tấn phù sa lơ lửng cho vùng hạ du ĐBSCL. Một phần trong số đó đã góp phần tham gia hình thành và phát triển nên vùng bãi bồi mũi Cà Mau, sau đó được đưa lên phía Nam, khu vực bờ biển Kiên Giang trong mùa gió Tây Nam. Tuy nhiên, tổng lượng dòng chảy và bùn cát vào ĐBSCL rất khác nhau theo các năm.

Những năm gần đây, khu vực thượng nguồn sông Mekong chứng kiến hàng loạt những thay đổi mạnh mẽ tác động trực tiếp đến dòng chảy của con sông. Trong đó xây dựng hồ chứa phục vụ thủy điện có mức độ ảnh hưởng mạnh mẽ nhất (Hình 4). [12] đã dự báo bùn cát lơ lửng sẽ bị suy giảm $60 \%$ nếu một nửa số đập thủy điện dự kiến hoàn thiện xây dựng. Và con số này sẽ là $96 \%$ khi toàn bộ các đập thủy điện này hoàn thiện. Mặc dù nghiên cứu này chưa cân nhắc đến phương pháp xả đáy, cũng như công tác nạo vét lòng hồ, nhưng con số này đã phần nào cho thấy hạ lưu ĐBSCL đang phải đối mặt với những nguy hiểm thực sự. 


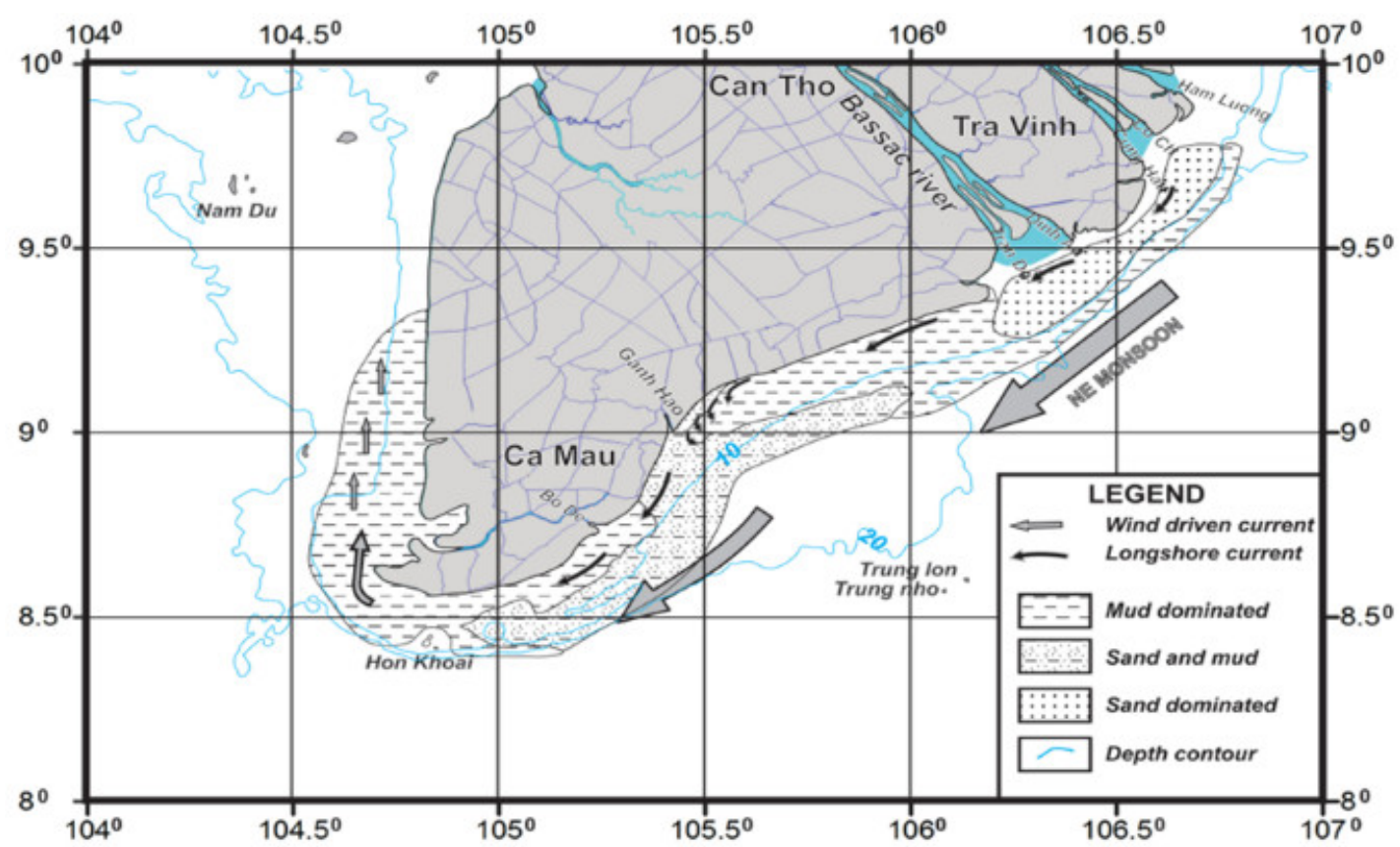

Hình 3. Bùn cát bồi lắng và dòng vận chuyển dưới tác động của gió mùa Đông Bắc [13].
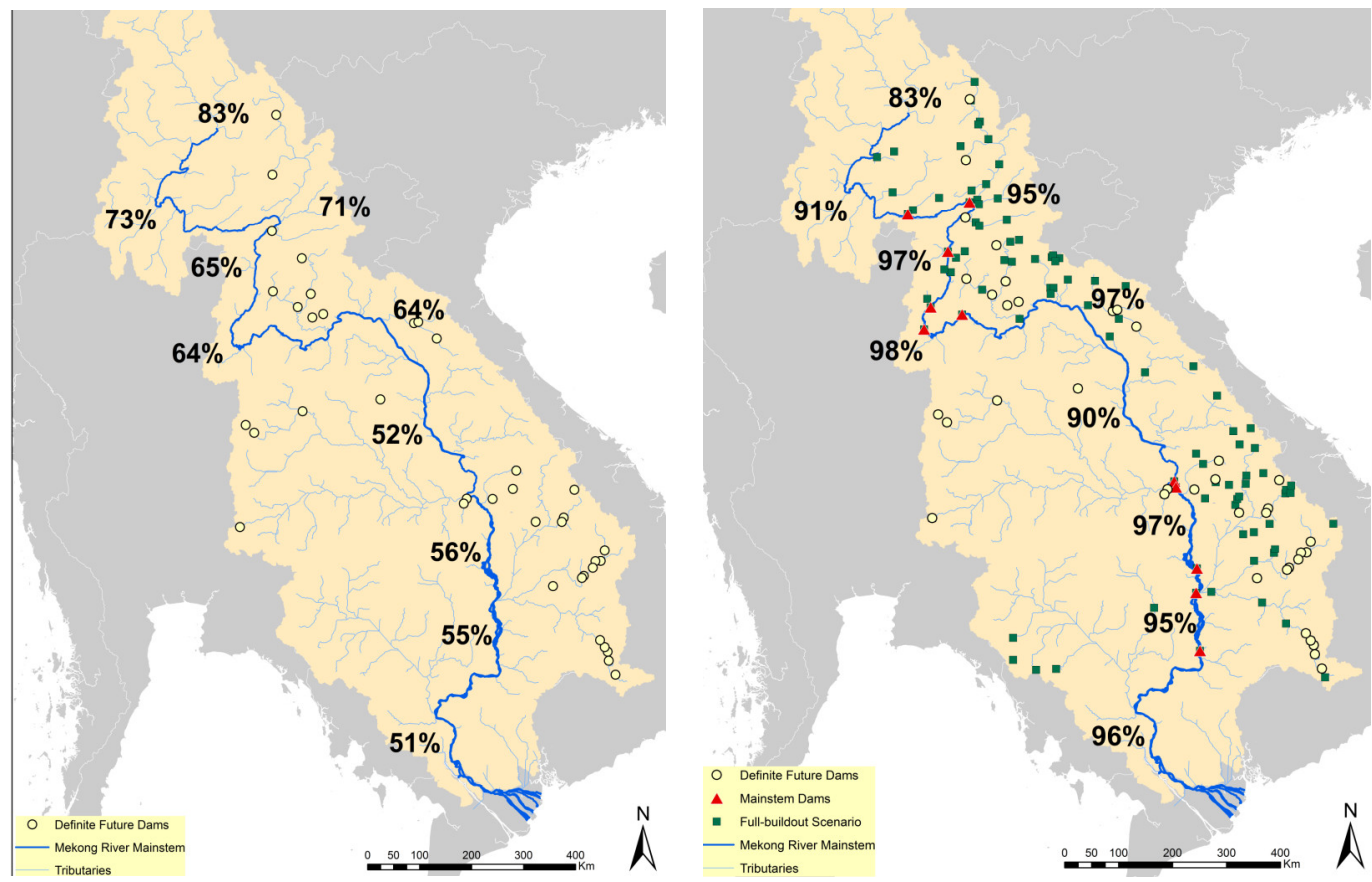

Hình 4. Mức độ suy giảm bùn cát lơ lửng theo mức độ phát triển đập thượng lưu [13].

\subsection{Biến đổi khí hậu}

Có thể nói, ảnh hưởng của biến đổi khí hậu (BĐKH) đối với các khu vực ven biển như bờ biển Tây, Kiên Giang là hoàn toàn có thể nhận thấy. Các cơ chế thứ sinh của BĐKH như thay đổi điều kiện thủy hải văn, mực nước biển dâng tác động trực tiếp đến quá trình xói lở đường bờ cũng như suy giảm RNM. Một mặt là tần suất và cường độ của điều kiện thời tiết cực đoan ngày càng tăng. Mặt khác nước biển dâng làm thay đổi điều kiện sinh thái của vùng nước ven bờ, RNM bị ngập sâu và lâu hơn trước (Hình 5). Điều này ảnh hưởng rất mạnh đến tiến trình sinh trưởng và phát triển của hệ sinh thái rừng. Như là một điều khó tránh khỏi, khi không còn sự che chở của hệ thống rễ cây RNM, bãi biển với bùn chiếm ưu thế sẽ nhanh chóng bị bào mòn dưới tác động của sóng và dòng chảy. 

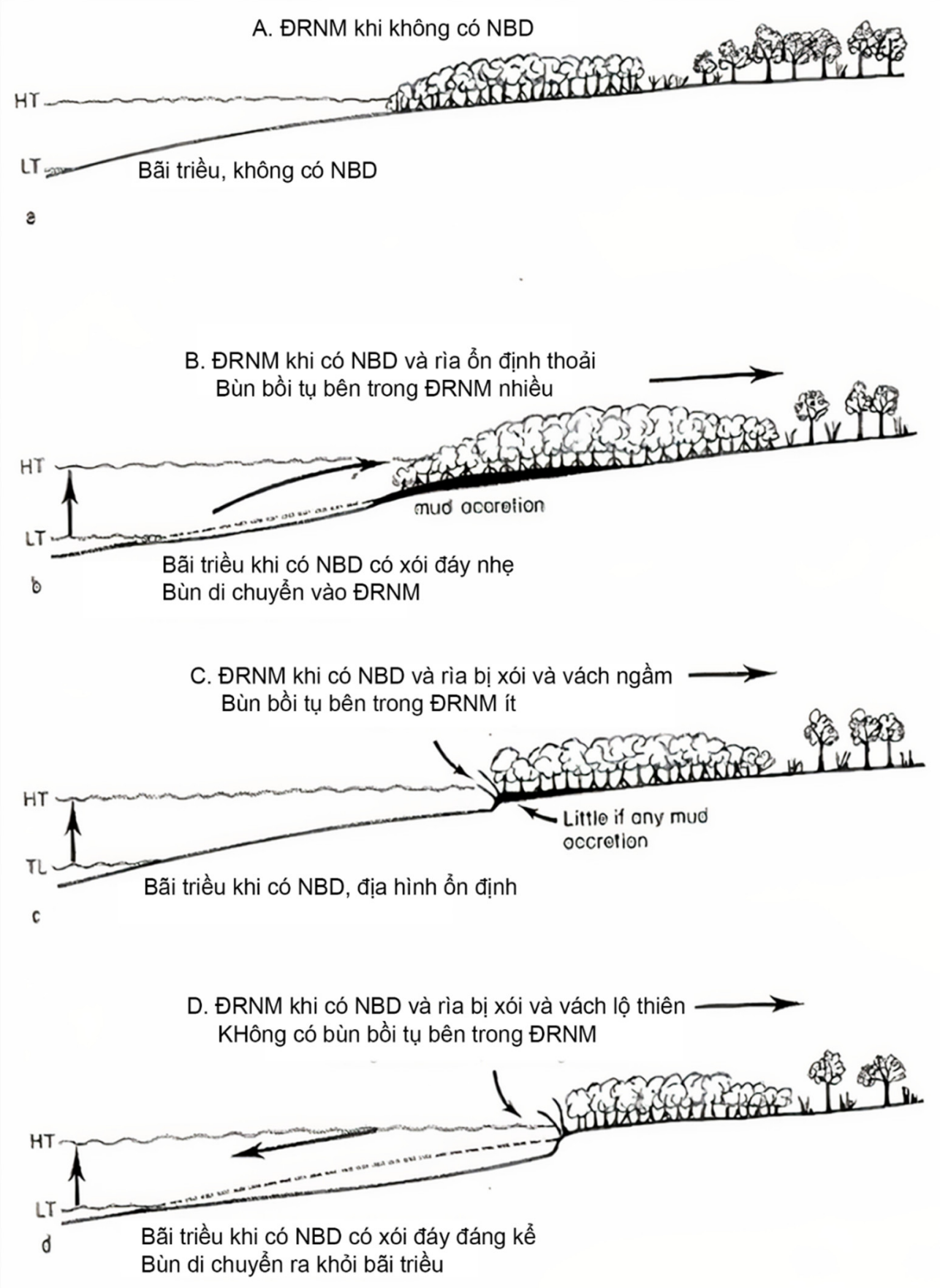

Hình 5. Rừng ngập mặn suy giảm dưới tác động của nước biển dâng.

Vấn đề này càng trở nên nghiêm trọng khi có sự cộng hưởng với hiện tượng lún sụt đất ở khu vực ĐBSCL. Tuy cơ chể này cần thêm thời gian để có những kết quả đo đạc có tính hệ thống và định tính trước khi đưa ra kết luận chính xác nhất, những số liệu ban đầu đã cho thấy xu thế này thực sự đang xảy ra. Lún sụt đất cộng hưởng với nước biển dâng làm gia tăng độ sâu nước nước bãi [14]. Điều này làm đường bờ bị sạt lở cho đến khi một trạng thái cân bằng mới được thiết lập với việc đường bờ bị lùn vào trong [15].

\subsection{Anh hưởng tù hoạt động của con người}

Mức độ và quy mô tác động ngày càng tăng của các tác nhân như: hoạt động kinh tế-xã hội và xây dựng các công trình hạ tầng (công trình thủy lợi, giao thông, đô thị hóa, khai thác RNM, phát triển ao nuôi tôm, xây dựng đê biển,...) tại ĐBSCL nói chung và vùng ven biển 
Tây, tỉnh Kiên Giang nói riêng [16]. Việc chuyển đổi một diện tích lớn và chuyển đổi quá nhanh từ sản xuất cây con nước ngọt sang nuôi tôm nước lợ, nước mặn đã làm thay đổi đột ngột về hệ sinh thái và môi trường nước. Quá trình này đang ảnh hưởng mạnh mẽ đến khả năng phát triển bền vững của hệ sinh thái RNM.

\section{Kết quả và thảo luận}

\subsection{Các giải pháp bảo vệ bờ đã được ưng dụng tại ĐBSCL}

\subsection{1. Đê biển}

Đây là loại công trình được ứng dụng sớm nhất ở ĐBSCL với mục tiêu ban đầu là quản lý tài nguyên nước. Đê biển được bố trí trong tổng thể một hệ thống công trình thủy lợi, thường là phối hợp với cống và trạm bơm (Hình 6). Mục đích của hệ thống công trình này cho vùng ĐBSCL lúc bấy giờ là tạo ra một vùng ngọt để mở rộng diện tích canh tác nông nghiệp, chủ yếu là lúa nước. Hầu hết các tuyến đê biển ở ĐBSCL được đầu tư xây dựng rải rác trong giai đoạn từ năm 1986-2000. Kết cấu công trình phần lớn là đê đất, để ngăn nước triều dâng. Qua nhiều thập kỷ, tuyến đê biển này, đặc biệt là phía biển Tây, đã làm việc rất ổn định. Một phần là nhờ tuyến đê này ít phải chịu ảnh hưởng trực tiếp từ sóng do được che chắn sau dải RNM ven biển ở khu vực này.
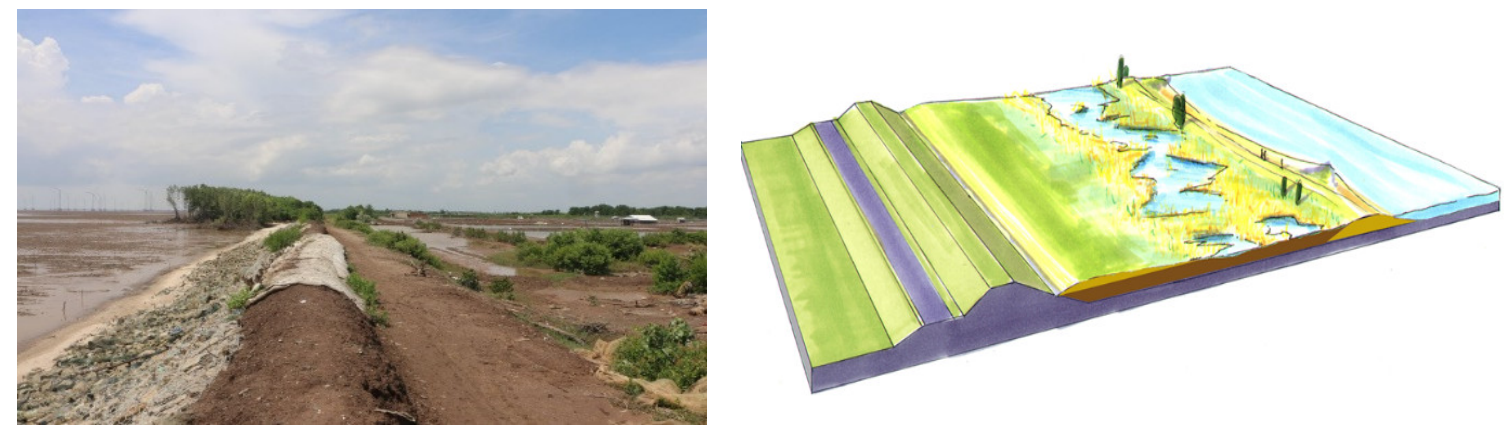

Hình 6. Vị trí đê biển trong tương quan với dải rừng trước bãi.

Tuy nhiên, trước xu thế suy giảm nhanh chóng của dải RNM nói trên, hàng trăm kilômét đê biển đã phải phơi mình trực tiếp đối diện với sóng (Hình 7). Thiết kế đê đất không phải là một giải pháp tối ưu cho điều kiện này, dẫn đến việc tuyến đê này đang bị đe dọa nghiêm trọng [17].

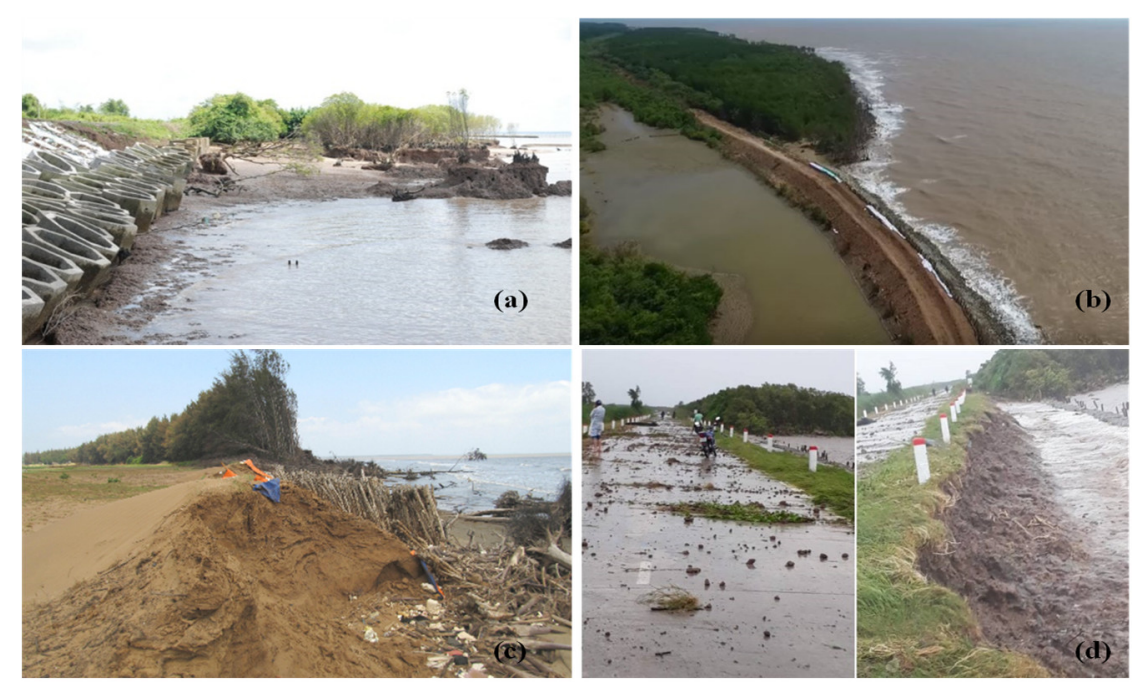

Hình 7. Dải rừng ngập mặn ven biển tiêu biến làm lộ tuyến đê đất: (a) Gò Công, Tiền Giang; (b)

Vĩnh Châu, Sóc Trăng; (c) Bạc Liêu; (d) Cà Mau. 
Ngược lại, có những bằng chứng cho thấy tuyến đê biển hay các dạng công trình thuỷ lợi khác có khả năng là một trong những tác nhân góp phần làm suy giảm dải RNM ven biển theo thời gian (Hình 8, Hình 9).
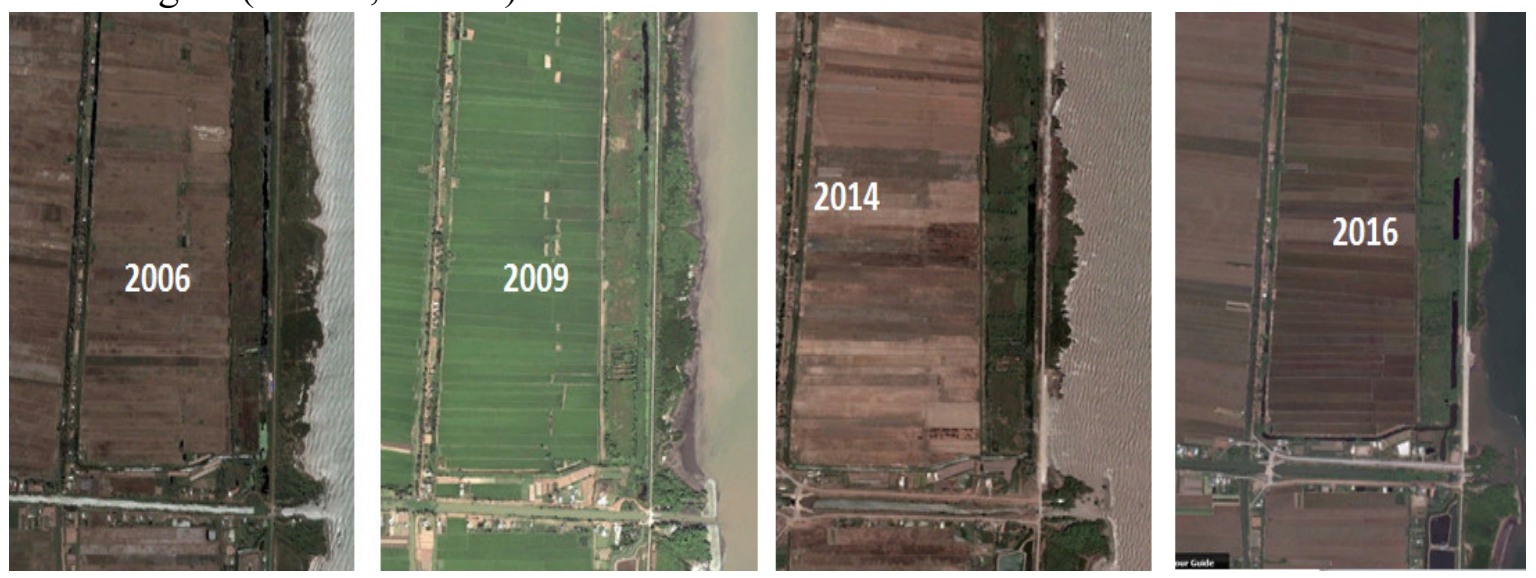

Hình 8. Rừng ngập mặn ven biển trước đê biển Tân Thành, Tiền Giang (ảnh Google Earth).

Những kiến thức về sinh trưởng của RNM có thể cung cấp những cơ sở khoa học để lý giải cho mối quan hệ này. Trong số đó có thể kể đến: (i) cây RNM không hoàn toàn sống trong môi trường nước mặn, mà cần được định kỳ được pha loãng bằng nguồn nước ngọt từ bờ chảy ra; (ii) nước ngọt từ các hệ thống kênh bị chặn và điều tiết bởi hệ thống cống, dẫn đến việc bùn cát và đặc biệt là dưỡng chất trong bùn cát lơ lửng này không được cung cấp thường xuyên cho vùng RNM, dẫn đển cây bị thiếu chất và suy kiệt; (iii) thiết kế đê biển dù có mái dốc, nhưng vẫn là rất đứng khi so với độ dốc tự nhiên của bãi biển (1/3 so với 1/500), dẫn đến sóng phản xạ thay đổi khác thường so với trước khi có công trình. Tuy nhiên, đến nay vẫn chưa có nhiều nghiên cứu thực sự đi sâu vào làm rõ mối tương quan này [6].
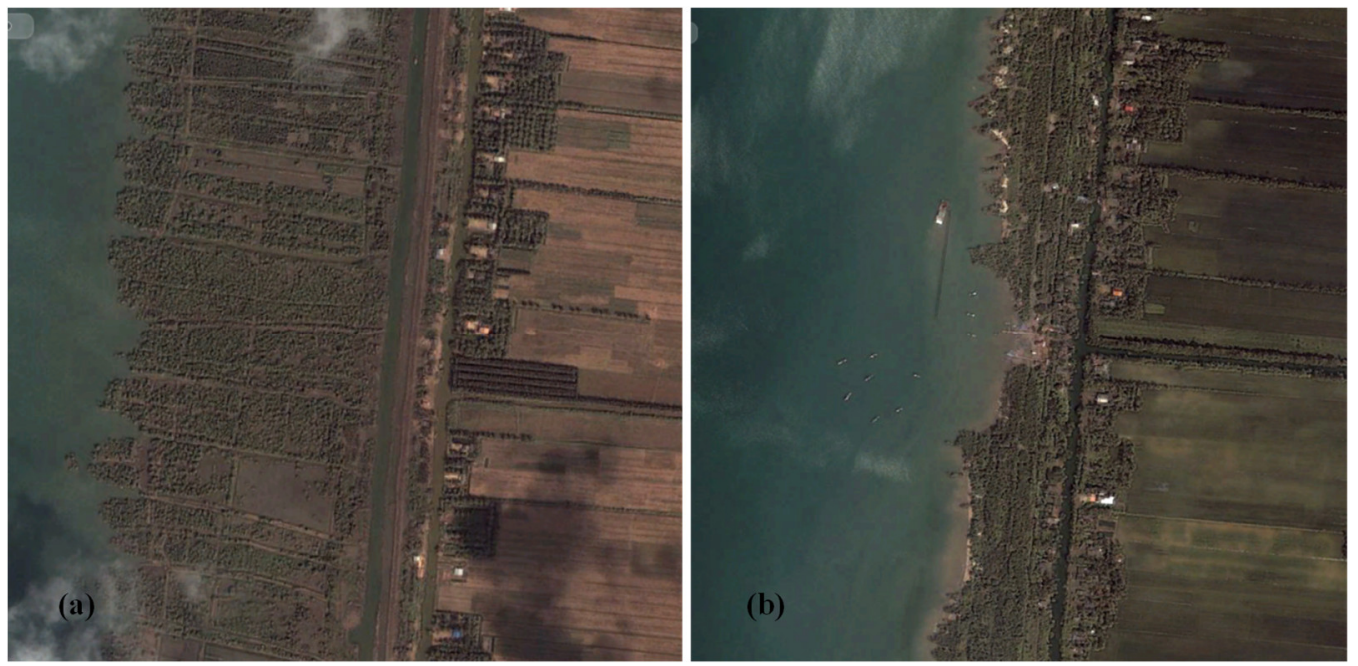

Hình 9. Bãi và dải rừng ngập mặn thay đổi trước và sau khi thi công cống thủy lợi ở biển Tây Cà

Mau (ảnh Google Earth): (a) 2001; (b) 2013 sau khi cống hoàn thành.

\subsubsection{Kè mái nghiêng}

Như đã đề cập ở phần trước, loại công trình này hiện đang được ứng dụng rất rộng rãi ở ĐBSCL do tính tức thì của nó trong công tác bảo vệ bờ trước tác động của sóng và dòng chảy. Ngược lại với kè phá sóng, kè mái nghiêng (Hình 10) bảo vệ trực tiếp đường bờ nơi kè được thi công, mà không phải là hiệu chỉnh dòng chảy để đồng bảo vệ bãi biển trước mặt kè. Mặt trái của giải pháp này trước hết là chi phí thi công. 


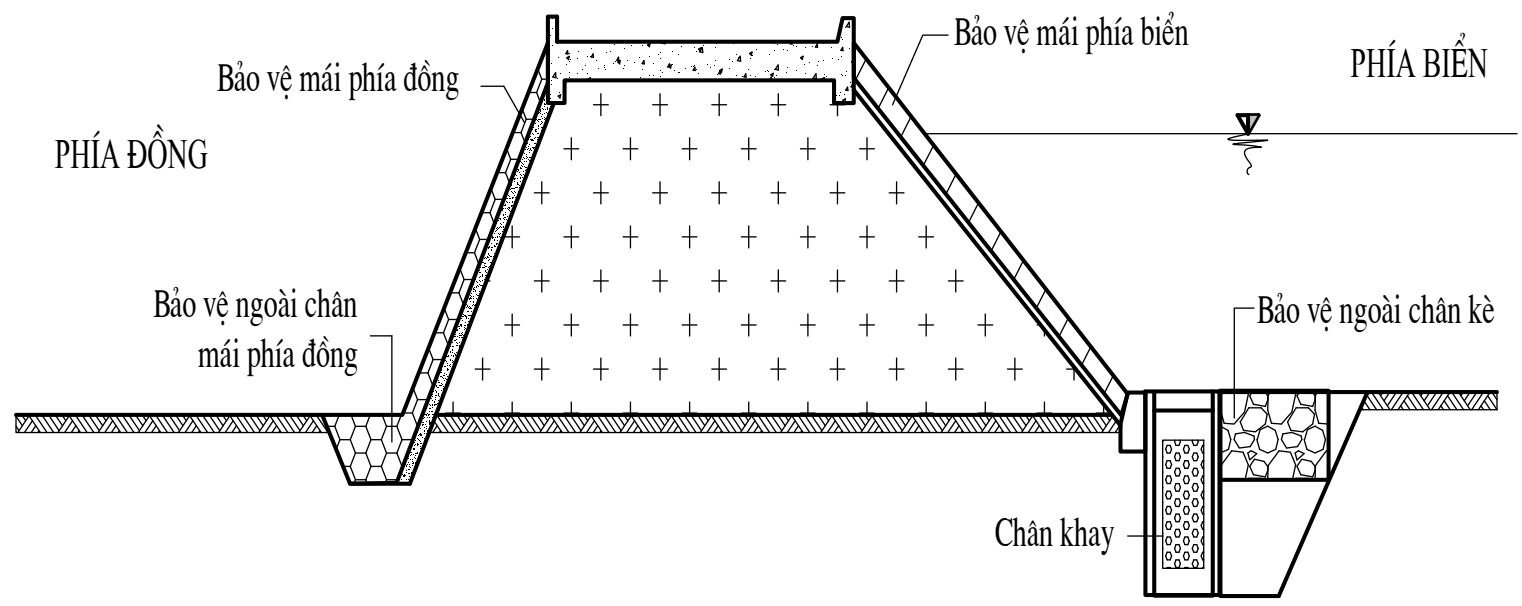

Hình 10. Một mặt cắt điển hình tuyến đê biển được bảo vệ bởi kè mái nghiêng.

Do vật liệu xây dựng (thường là đá đổ hoặc khối bê tông lắp ghép) có chi phí cao. Nhược điểm tiếp theo của giải pháp này là do việc cứng hóa đường bờ, bãi trước kè sẽ phải đối diện với nguy cơ xói lở cao hơn do ảnh hưởng của sóng phản xạ. Việc cứng hóa này cũng tiềm ẩn rủi ro về mất cân bằng vận chuyển bùn cát dọc bờ, dẫn đến những khu vực lân cận không được bảo vệ sẽ bị xói lở. Ngoài ra, với trọng lượng công trình khá lớn, việc thi công ở những khu vực có nền đất mềm yếu như bờ biển Tây ĐBSCL cũng là một trở ngại lớn (Hình 11).
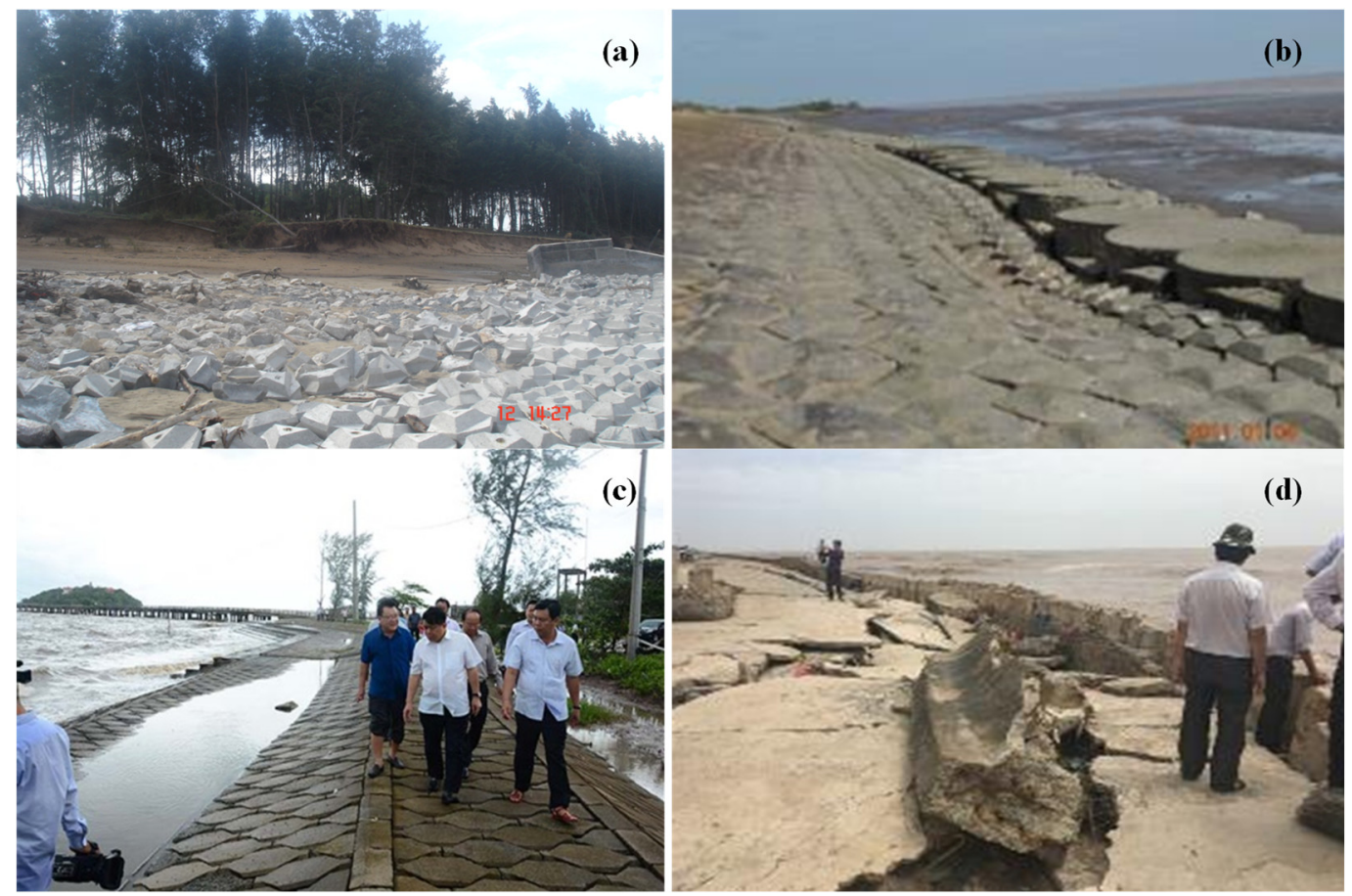

Hình 11. Điển hình công trình kè biển bị hư hỏng do chuyển vị nền móng yếu: (a) Trà Vinh; (b) Tiền Giang; (c) Cà Mau; (d) Bạc Liêu.

\subsection{3. Đê phá sóng đá đổ}

Đây là một trong những kết cấu lâu đời nhất của công trình biển nói riêng và công trình thủy nói chung. Thường được sử dụng cho những khu vực cảng biển nước sâu. Kết cấu này phải chống chọi trực tiếp với sóng trong những điều kiện thời tiết cực đoan nhất (Hình 12) [18]. 


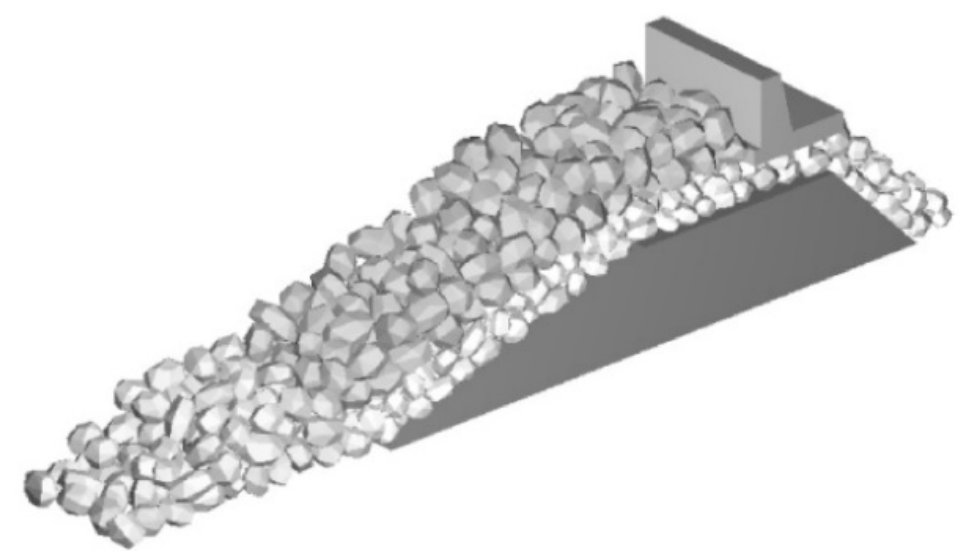

Hình 12. Mặt cắt điển hình của đê phá sóng đá đổ.

Tuy nhiên, loại công trình rất hiếm ở khu vực ven biển ĐBSCL vì lý do khối lượng công trình rất lớn. Để công trình có thể làm việc hiệu quả và ổn định ở khu vực bờ biển này, nền móng cần phải được gia cố hoặc thậm chí là cải tạo. Kết hợp với việc đá không phải phải là vật liệu địa phương ở khu vực này, dẫn đến chi phí thi công rất cao. Hiện nay chỉ có cảng nhà máy nhiệt điện Trà Vinh là đang sử dụng loại công trình này để bảo vệ cho khu cảng nhập nguyên liệu của nhà máy (Hình 13).
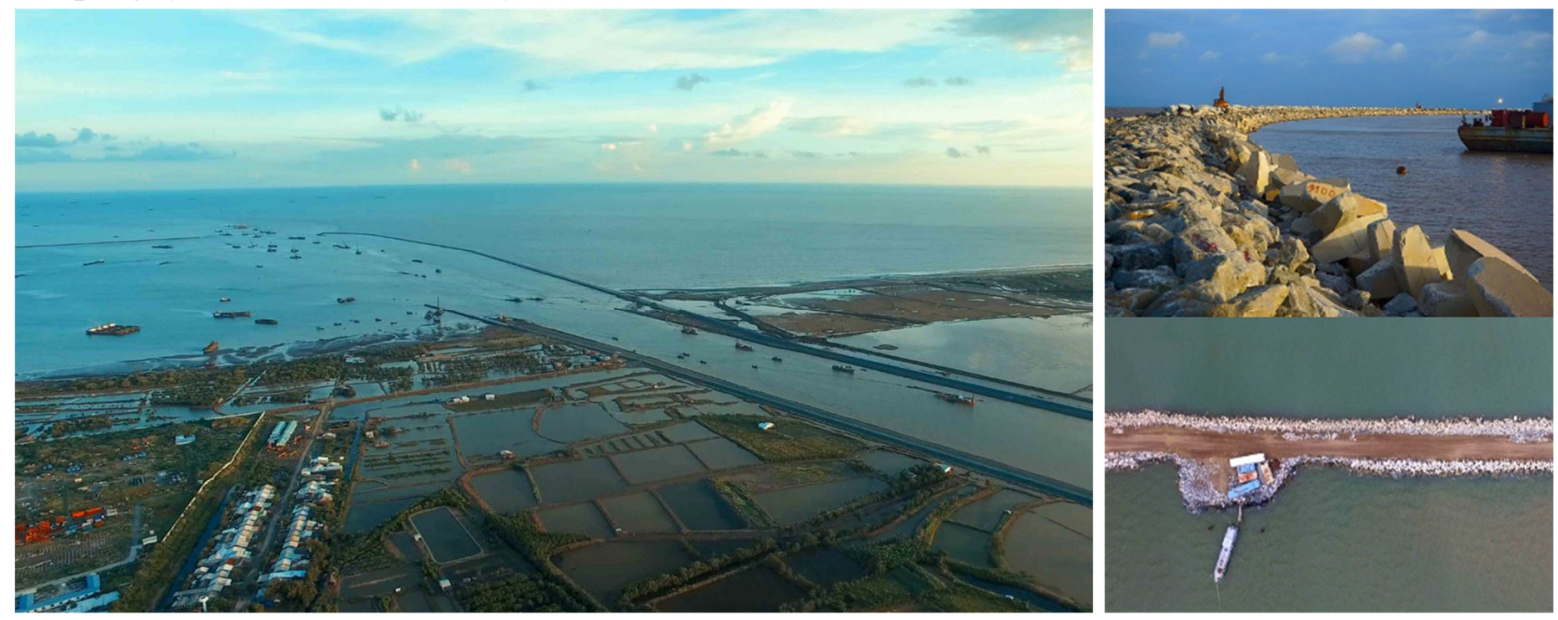

Hình 13. Đê phá sóng dạng đá đổ nhà máy nhiệt điện Trà Vinh.

\subsection{4. Đê phá sóng dạng hỗn hợp}

Hiện nay, với nhu cầu bức thiết phải tìm ra giải pháp kết cấu vừa đạt được yêu cầu tiêu giảm sóng để bảo vệ bờ, mà vẫn đảm bảo tính ứng dụng rộng rãi nhờ giá thành hợp lý. Nhiều giải pháp kết cấu đã được đề xuất và thử nghiệm. Trong đó, có thể kể đến đê phá sóng sóng dạng hỗn hợp. Ý tưởng tổng quát của dạng kết cấu này là phối hợp kết cấu dạng cọc đóng vào nền đất mềm yếu để đảm bảo tính ổn định công trình, sau đó kết hợp với các loại vật liệu khác để đảm bảo khả năng che chắn sóng. Hai loại công trình điển hình cho kết cấu này là: (i) đê phá sóng cọc tre và bè cành cây; (ii) đê phá sóng cọc bê tông ly tâm kết hợp với đá đổ.

\subsection{5. Đê phá sóng cọc tre và bè cành cây}

Tính đến nay, tổng cộng đã có $7.100 \mathrm{~m}$ kè được thi công ở bờ biển phía đông ĐBSCL và phía biển Tây con số này là $26.000 \mathrm{~m}$ [19]. Đây là một giải pháp được nhắm thẳng đến mục tiêu chi phí thấp, bằng cách sử dụng vật liệu địa phương, đơn giản và phổ biến. Thêm vào đó, vật liệu có tự nhiên, được kỳ vọng ít có ảnh hưởng đến môi trường thủy sinh. Tuy 
nhiên, các công trình này hiện đang cho thấy tuổi thọ công trình ngắn, đồng thời hiệu quả tiêu giảm sóng tương đối giới hạn. Nhìn chung, loại công trình này chỉ phù hợp cho những khu vực không phải đối mặt với sóng lớn $(\mathrm{Hs}<0,9 \mathrm{~m}, \mathrm{Tp}<8 \mathrm{~s})$. Đối với những bãi biển có độ dốc lớn, loại công trình này cũng không có nhiều tính khả thi. Mô hình này đã được thử nghiệm ở Kiên Giang (Hình 14), đã chứng minh được phần nào tính phù hợp cho khu vực đường bờ ở khu vực này.

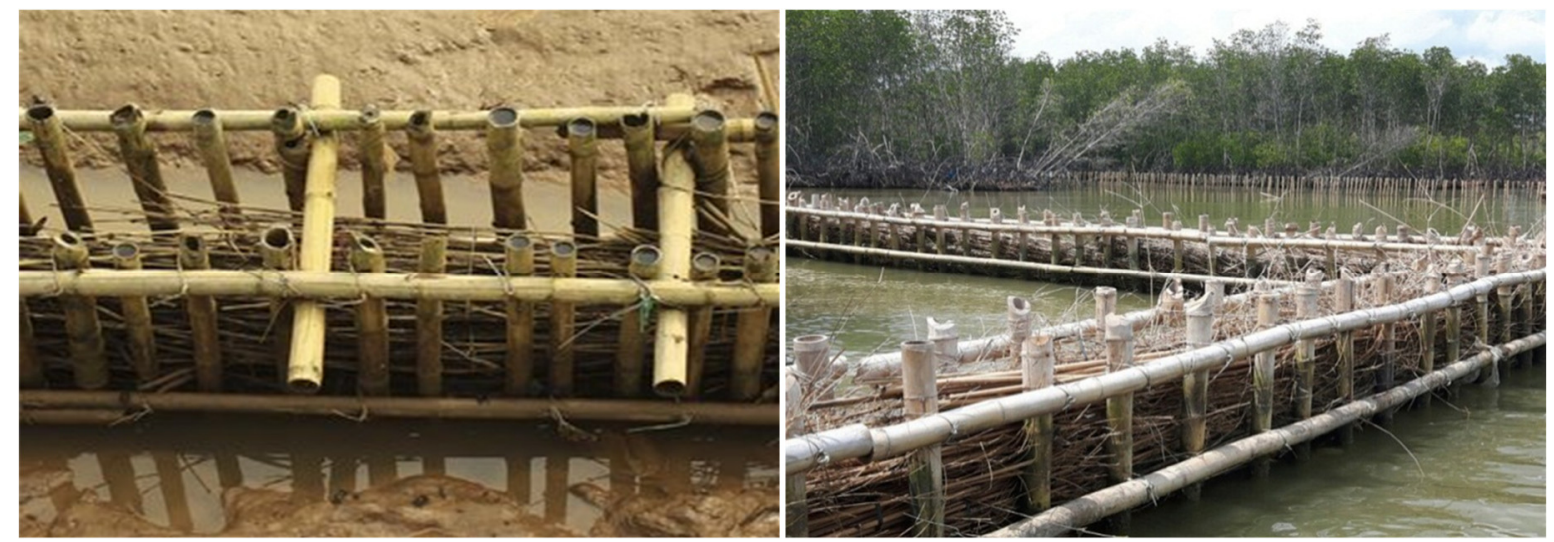

Hình 14. Kết cấu điển hình của đê phá sóng cọc tre và bè cành cây.

\subsection{5. Đê phá sóng cọc ly tâm đá đổ}

Tương tự như đê phá sóng cọc tre và bè cành cây, đê phá sóng cọc ly tâm đá đổ thay cọc tre bằng cọc bê tông và bè cành cây bằng đá đổ. Cọc bê tông ly tâm thường có chiều dài từ khoảng 5-7 m, đường kính D300. Cọc được đóng thành hao hàng, song song nhau, kết nối bằng dầm bê tông hoặc thép để tạo thành bộ hệ khung. Giữa hai hàng cọc, đá được đổ vào để tăng khả năng chen chắn và phá sóng (Hình 15).
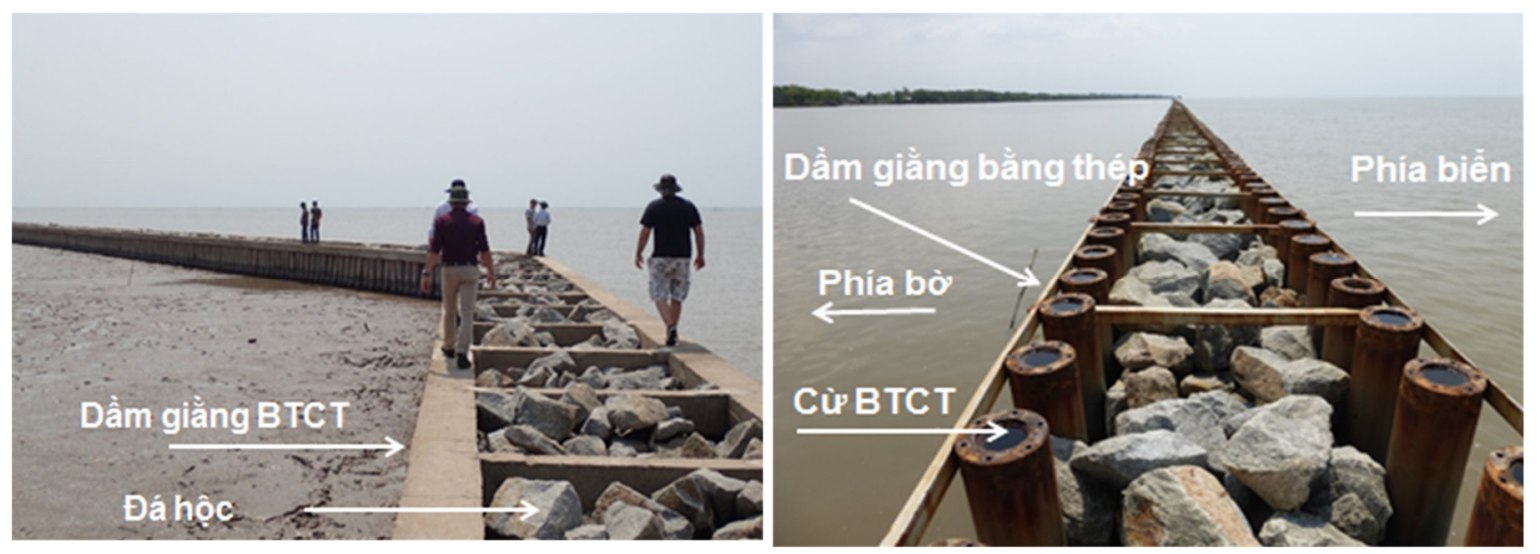

Hình 15. Kết cấu điển hình của đê phá sóng dạng cọc bê tông ly tâm đá đổ.

Không như dạng cọc tre và bè cành cây, đê phá sóng cọc ly tâm đá đổ có tuổi thọ công trình dài hơn rất nhiều lần. Phạm vi ứng dụng cũng linh hoạt hơn, đặc biệt là công trình có thể làm việc được ở những khu vực có độ sâu trên $2 \mathrm{~m}$ [20].

\subsection{Các giải pháp mói}

Hiện tại có rất nhiều giải pháp đang được nghiên cứu và đề xuất. Một vài trong số đó đã được thử nghiệm ngoài hiện trường, và hầu hết vẫn còn đang trong giai đoạn đánh giá tính hiệu quả. Có thể kể đến như: Giải pháp công trình "mềm", thường là túi geotextile, chứa cát (Hình 16,17). Được đề xuất dựa trên hướng tiếp cận giá thành thấp, thi công nhanh chóng, và linh hoạt trong ứng dụng trên nền móng yếu. 


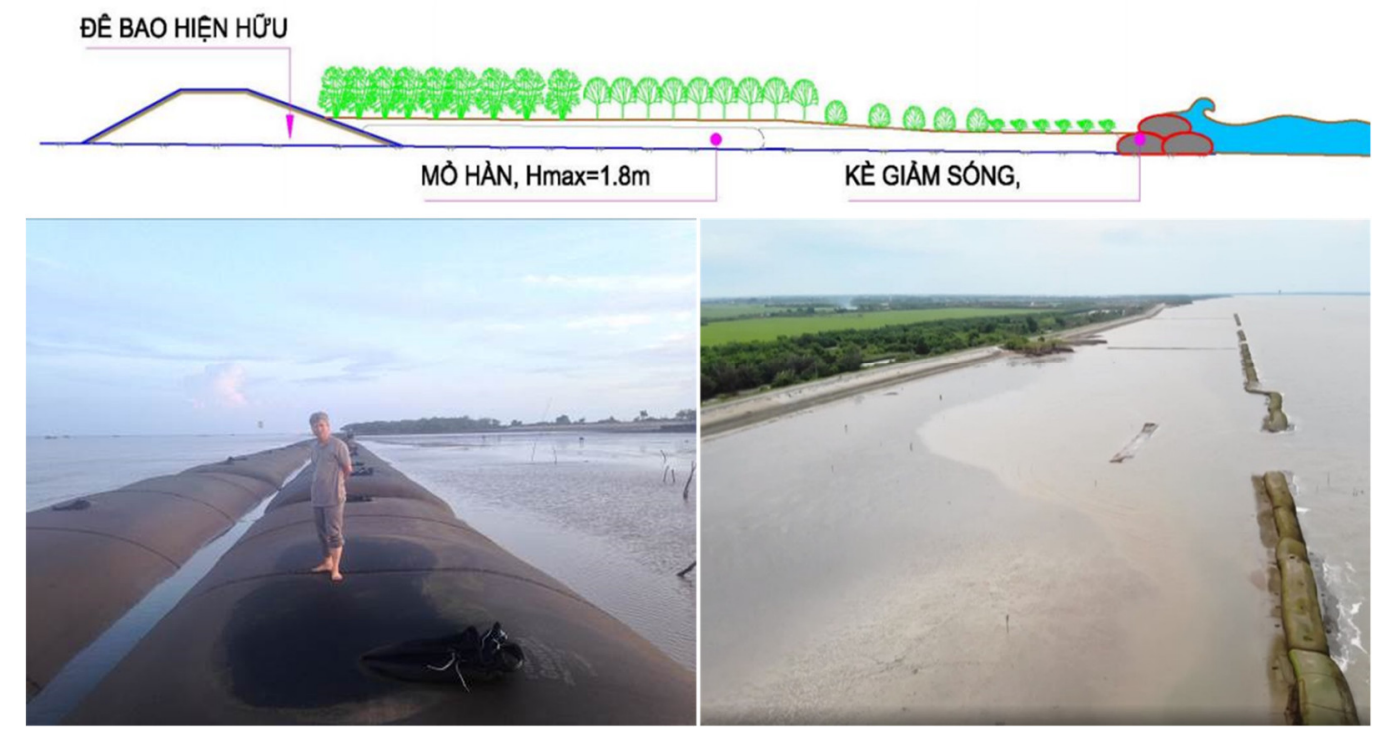

Hình 16. Đê phá sóng xa bờ bằng ống Geotextile - Gò Công, Tiền Giang.
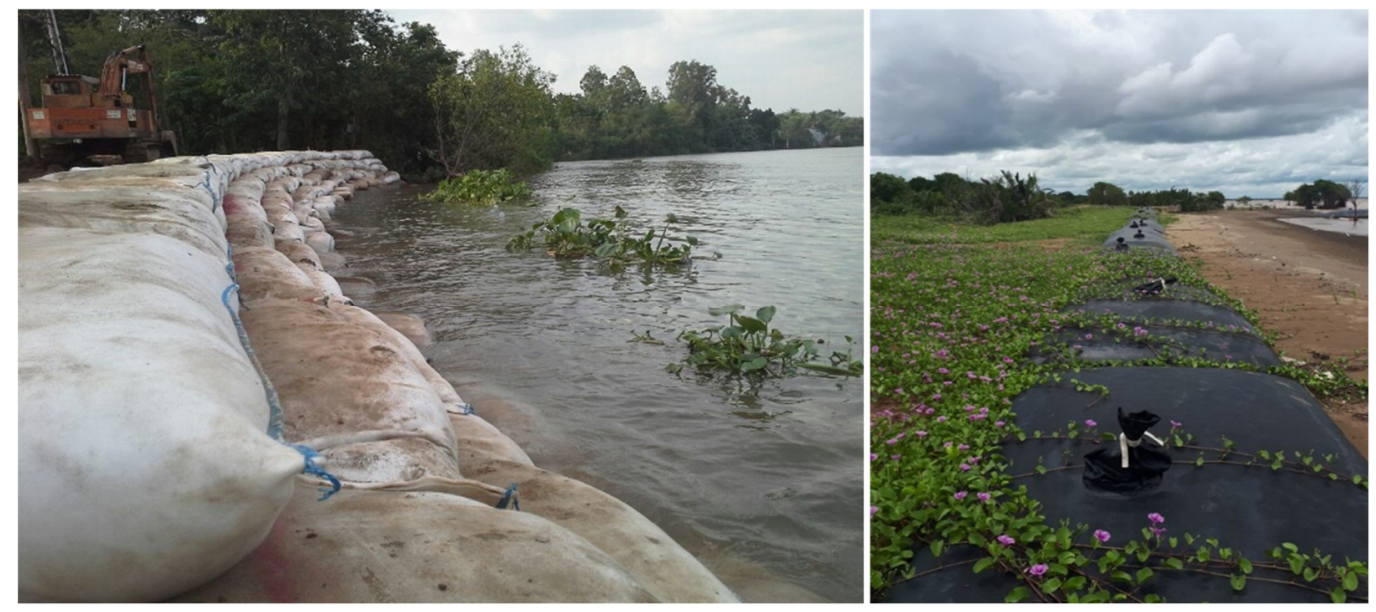

Hình 17. Kè bảo vệ bằng túi và ống.

Đê phá sóng dạng khối rỗng: ý tưởng nhắm đến giải pháp công trình khối đúc sẵn, vật liệu phần lớn là bằng bê tông cốt thép. Yếu tố cốt lõi trong ý tưởng này là khả năng thi công nhanh chóng, nhờ việc sử dụng những khối bê tông đúc sẵn. Điều này giúp giảm đáng kể giá thành thi công công trình, đặc biệt là trong điều kiện sóng biển. Nhiều loại kết cấu đã được nghiên cứu và thử nghiệm ngoài hiện trường (Hình 18).
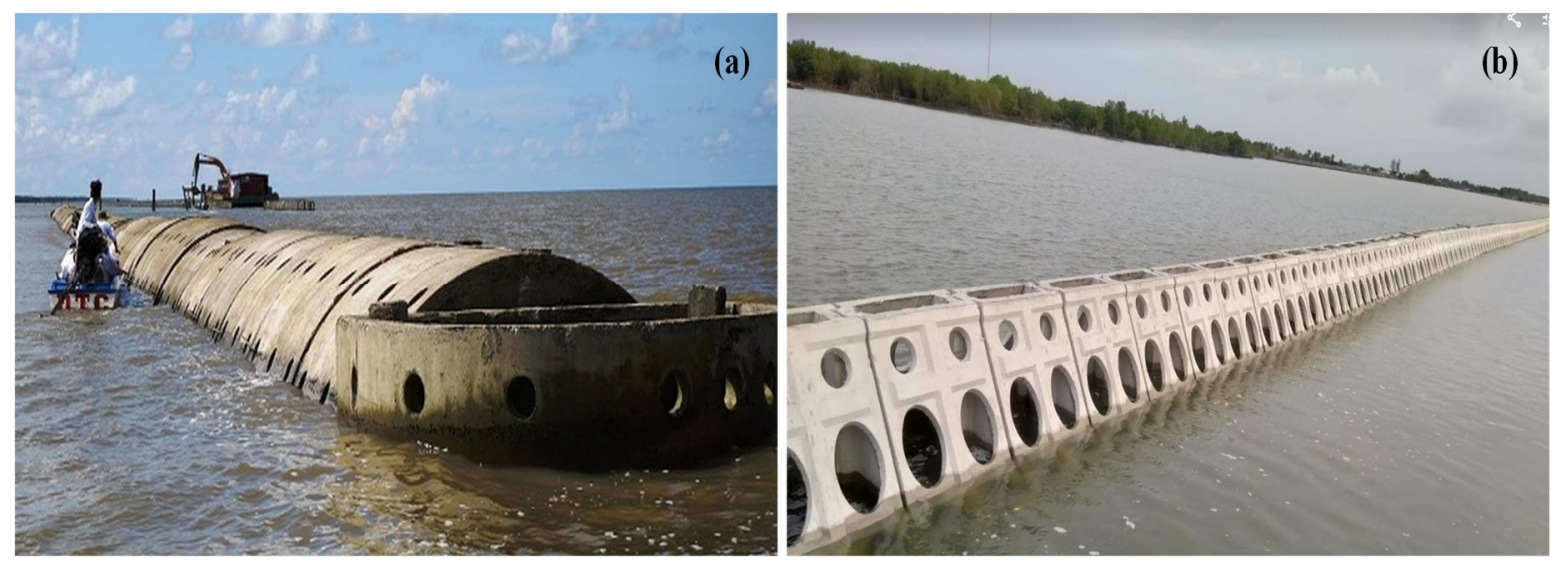

Hình 18. (a) Đê trụ rỗng-Viện thủy công; (b) Đê phá sóng dạng rỗng-Busadco. 
Tuy nhiên, do công trình có tính thử nghiệm. Nhiều tham số thiết kế không rõ ràng, dẫn đến tỷ lệ thất bại không nhỏ (Hình 19) [20].

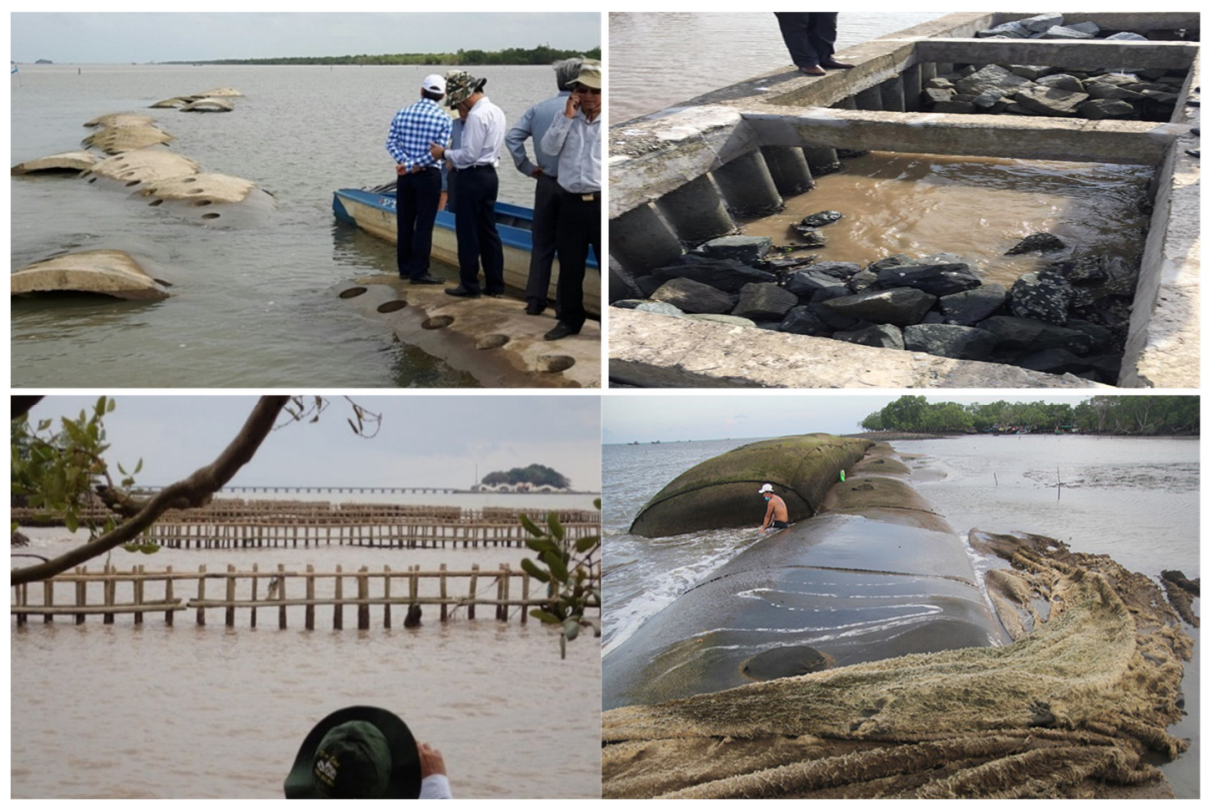

Hình 19. Các kết cấu mới bị hư hỏng trong giai đoạn thử nghiệm.

\section{Kết luận và kiến nghị}

RNM khu vực ĐBSCL đóng vai trò vô cùng quan trọng trong quá trình phát triển bền vững của vùng. Bảo tồn diện tích rừng còn hiện hữu, tiến đến phục hồi diện tích rừng đã mất là mục tiêu sống còn nếu muốn duy trì sự ổn định của vùng ĐBSCL. Nhiều giải pháp cả công trình lẫn phi công trình đang được được đề xuất cho nghiên cứu cũng như thử nghiệm. Nhiều cơ quan nghiên cứu cũng như chuyên gia đã vào cuộc tham gia đóng góp ý kiến chuyên môn cũng như chia sẻ kiến thức để cùng giải quyết vấn đề rất lớn này. Bài báo này đã đánh giá được một cách có hệ thống các giải pháp đã và đang được áp dụng tại khu vực biển Tây, Kiên Giang nói riêng và vùng bờ biển ĐBSCL nói chung. Uuu và nhược điểm của từng giải pháp đã được khái quát mô tả để đưa ra một bức tranh chi tiết về tình trạng ứng dụng khoa học công nghệ trong lĩnh vực bảo vệ bờ ở đây. Sẽ cần nhiều hơn các nghiên cứu cụ thể, hay thậm chí là chuyên sâu để tối ưu một vài giải pháp có tính khả thi tốt. Tuy nhiên, hiện tại, có thể thể rút ra một vài điểm mấu chốt làm tiền đề cho các nghiên cứu chuyên sâu tiếp theo.

Các giải pháp công trình hoặc phi công trình cần phải xem xét tính hài hòa với thiên nhiên (Building with Nature). Uu tiên các giải pháp hỗ trợ để thiên nhiên tự giải quyết vấn đề. Bằng cách này có thể giúp tìm ra các giải pháp có chi phí thấp, tính ứng dụng rộng rãi cao, và quan trọng hơn cả là giảm thiểu các tác động tiêu cực đến môi trường cũng như hệ sinh thái địa phương. Có thể cần phải cân nhắc đến giải pháp thiết lập lại vùng bãi triều tự nhiên cân bằng động lực bùn cát hạt mịn, loại bỏ hoặc chuyển đi các công trình cứng như đê, kè, bờ bao, ...trước rừng và trong rừng. Tăng khả năng bẫy bùn cát một cách tự nhiên trên bãi triều sử dụng rào chẳn cây nhỏ (thẩm thấu lớn), đào rãnh. Các giải pháp công trình giảm sóng nếu có cần có tính thấm lớn, không ngăn chặn sự trao đổi bùn cát, giảm được sóng phản xạ, hạn chế áp dụng công trình cứng. Trồng tái sinh loại cây thích hợp ở nơi phù hợp ở những nơi rừng không có khả năng tự tái sinh, tốt nhất là tái tạo lại điều kiện cho rừng tự tái sinh (không cần trồng mới).

Đóng góp cho nghiên cứu: Xây dựng ý tưởng nghiên cứu: L.T.K.T., Đ.T.V., T.C.D., Lựa chọn phương pháp nghiên cứu: L.T.K.T., Đ.T.V., T.C.D., C.T.V.; Thu thập, phân tích, xử lý số liệu: Đ.T.V., N.H.T., T.K.N., T.C.D.; Viết bản thảo bài báo: Đ.T.V., T.C.D., C.T.V., N.H.T.; Chỉnh sửa bài báo: Đ.T.V. 
Lời cảm ơn: Kết quả nghiên cứu trong bài báo này được thực hiện với sự tài trợ của đề tài cấp Bộ 2018: "Nghiên cứu đặc điểm xói lở, đề xuất giải pháp phục hồi và phát triển rừng ngập mặn ven biển Tây Nam Bộ; Thử nghiệm tại huyện An Minh, tỉnh Kiên Giang”, Mã số: TNMT.2018.06.09 do Trường Đại học Tài nguyên và Môi trường Tp. Hồ Chí Minh chủ trì.

Lời cam đoan: Tập thể tác giả cam đoan bài báo này là công trình nghiên cứu của tập thể tác giả, chưa được công bố ở đâu, không được sao chép từ những nghiên cứu trước đây; không có sự tranh chấp lợi ích trong nhóm tác giả.

\section{Tài liệu tham khảo}

1. Cunnh-Lignon M.; Mehiques, M.M.; Schaeffer-Novelli, Y.; Rodrigues, M.; Klein, D.A.; Goya, S.C. Analysis of mangrove forest succession, using sediment cores; a case study in the cananeia-iguape coastal system, Sao Paublo, Brazil. Braz. J. Oceanogr. 2009, 57(3), 161-174.

2. Sở Nông nghiệp và Phát triển nông thôn tỉnh Cà Mau. Hiện trạng sạt lở bờ sông, đê biển và bờ biển, 2011.

3. Sở nông nghiệp và phát triển nông thôn tỉnh Cà Mau. Báo cáo hiện trạng sạt lở bờ sông, đê biển và bờ biển, 2006.

4. Nhân, N.H. Giải đoán ảnh viễn thám về biến động địa hình địa mạo, vùng nghiên cứu, xây dựng các bản đồ tỷ lệ $1: 10.000$. Nghiên cứu cơ chế hình thành và phát triển vùng bồi tự ven bờ và các giải pháp khoa học và công nghệ để phát triển bền vững về kinh tế-xã hội vùng biển Cà Mau. Báo cáo chuyên đề, 2015.

5. Buckton, S.T.; Tú, N.Đ.; Quỳnh, H.Q. Bảo tồn các vùng đất ngập nước quan trọng ở Đồng bằng sông Cửu Long, Hà Nội, 1999.

6. Thắng, T.Đ. Nghiên cứu các giải pháp thủy lợi nhằm khai tác bền vùng bán đảo Cà Mau, Báo cáo tổng kết đề tài cấp Nhà nước, 2012.

7. Li, X.; Liu, J.P.; Saito, Y.; Nguyen, V.L. Recent evolution of the Mekong Delta and the impacts of dams. Earth Sci. Rev. 2017, $175, \quad 1-17$. https://doi.org/10.1016/j.earscirev.2017.10.008.

8. Tú, N.V.; Lai, B. Bước đầu nghiên cứu chu trình sinh địa hóa và sự hình thành rừng ngập mặn tại bãi bồi đất mũi Cà Mau. Tạp chí Sinh hoc 2012, 34(3SE), 57-62.

9. Đinh, V.T.; Nguyễn, Đ.D.; Vũ, V.H. Biến động đường bờ vùng ven biển cửa sông Mekong với tác động của biến đổi khí hậu, 2010.

10. Lai, $B$. Sự hành và diễn thế rừng ngập mặn cửa sông viên biển Nam Bộ: Nghiên cứu quá trình tương tác biển-lục địa và ảnh hưởng của chúng đến các hệ sinh thái ven bờ Đông và Tây Nam bộ. Báo cáo tổng hợp Đề tài cấp nhà nước, 2010.

11. Lovelock, C.E.; Sorrell, B.K.; Hancock, N.; Hua, Q.; Swales, A. Mangrove Forest and Soil Development on a Rapidly Accreting Shore in New Zealand. Ecosystems 2010, 13, 437-451. https://doi.org/10.1007/s10021-010-9329-2.

12. Kondolf, G.M.; Rubin, Z.K.; Minear, J.T. Dams on the Mekong: Cumulative sediment starvation. Water Resour. Res. 2014, 50, 5158-5169. https://doi.org/10.1002/2013WR014651.

13. Thanh, N.T.; Stattegger, K.; Unverricht, D.; Nittrouer, C.; Phach, P.V.; Liu, P.; DeMaster, D.; Dung, B.V.; Anh, L.D.; Dong, M.D. Surface sediment grain-size distribution and sediment transport in the subaqueous Mekong Delta, Vietnam. $V N$ J. Earth Sci. 2017, 39(3), 193-209. https://doi.org/10.15625/0866-7187/39/3/10266.

14. van Rjin, L.C. Principles of sedimentation and erosion engineering in rivers, estuaries and coastal seas. The Netherlands: Aqua publication, 2012, pp. 623.

15. Paul, B.K.; Rashid, H. Climatic hazards in coastal Bangladesh: Non-structural and structural solutions/ Bimal Paul, Harun Rashid. Amsterdam: ButterworthHeinemann, 2016. 
16. Truong, T.D.; Do, L.H. Mangrove forests and aquaculture in the Mekong river delta. Land Use Policy 2018, 73, 20-28. https://doi.org/10.1016/j.landusepol.2018.01.029.

17. Nicholls, R.J.; Wong, P.P.; Burkett, V.; Codignotto, J.; Hay, J.; McLean, R.; Ragoonaden, S.; Woodroffe, C.D.; Abuodha, P.A.O.; Arblaster, J.; Brown, B.; Forbes, D.; Hall, J.; Kovats, S.; Lowe, J.; McInnes, K.; Moser, S.; Rupp-Armstrong, S.; Saito, Y. Coastal systems and low-lying areas. 2007. https://ro.uow.edu.au/scipapers/164.

18. US Army Corps of Engineers. Coastal Groins and nearshore breakwater, 1992.

19. Nguyet-Minh, N.; Cong-San, D.; Van-Duong, D.; Xuan-Tu, L.; Nestmann, F.; Zemann, M.; Thai-Duong, V.H.; Cong-Dan, T. Evaluating the Effectiveness of Existing Coastal Protection Measures in Mekong Delta. In: Trung Viet N., Xiping D., Thanh Tung T. (eds) APAC 2019. APAC 2019. Springer, Singapore. https://doi.org/10.1007/978-981-15-0291-0_192.

20. Nhan, N.H. Vài đánh giá tác động của tuyến kè ngầm tạo bãi ven biển tỉnh Cà Mau. 2014, 4-11.

\title{
Review of potential measures for recovering and developing mangrove forest in west coastal zone of Mekong delta, Vietnam
}

\author{
Doan Thanh Vu ${ }^{*}$, Trinh Cong Dan ${ }^{2}$, Hoang Thi To Nu${ }^{1}$, Nguyen Huu Tuan ${ }^{1}$, Can Thu \\ Van ${ }^{1}$ \\ ${ }^{1}$ Ho Chi Minh City University of Natural Resources and Environment; \\ dtvu@hcmunre.edu.vn; nu.htt@hcmunre.edu.vn; nhtuan@hcmunre.edu.vn; \\ ctvan@hcmunre.edu.vn. \\ ${ }^{2}$ Institute Of Coastal And Offshore Engineering; trinh.cong.dan@gmail.com.
}

\begin{abstract}
Mangrove forest in West coastal zone of Mekong Delta, Vietnam, plays a very important role for existence and sustainable development in both social and economical of low Mekong Delta. There more than $350 \mathrm{~km}$ of coast line run through Ca Mau and Ha Tien are fenced by mangrove. This is a very unique characteristics of this coastal zone when compare to other provinces of Vietnam in general and Mekong Delta in specific. Mangrove not only provide habitat for nearshore ecosystem, their roots act as fences protect the coast line from direct impact from waves and current, erosion driven forces. Unfortunately, these coast line is witnessing a reverse in morphological process. Many parts of the coast experience excessive erosion and forest degradation. The reasons could be linked to overexploit activities, climate change and land subsidence. This article is reviewing those reasons and propose corresponding measures to recover mangrove forest and regain land for west coast of Mekong Delta.
\end{abstract}

Keywords: Mangrove forest; Low Mekong delta; Coastal protection. 